\title{
GOOD CORPORATE GOVERNANCE (GCG) DALAM PRESPEKTIF ISLAM
}

\author{
M Shidqon Prabowo ${ }^{78}$
}

\begin{abstract}
Abstrak
Isu Good Corporate Governance (GCG) berkembang seiring terjadinya skandal keuangan yang menimpa beberapa perusahaan besar seperti Enron dan WorldCom. Indonesia sebagai negara berpenduduk mayoritas Islam tentunya harus mengetahui dan memahami prinsip GCG yang Islami dalam melaksanakan bisnis. Entitas syariah yang semakin berkembang menuntut para pelaku bisnis menerapkan GCG yang sesuai dengan prinsip syariah. GCG (Good Corporate Governance) adalah prinsip yang paling populer untuk menjaga integritas organisasi di dunia. Hampir semua negara di dunia terus prinsip ini untuk membangun akuntabilitas dan transparansi. Sayangnya, dalam kenyataannya, GCG memiliki penafsiran bahwa kurangnya nilai stakeholder.
\end{abstract}

\section{A. Latar Belakang Masalah}

Istilah Corporate Governance ditemukan pertama kali pada tahun 1984 pada tulisan Robert I. Tricker dalam bukunya Corporate Governance - Practices, Procedures, and Power in British Companies and Their Board of Directors, UK, Gower. Perhatian terhadap corporate governance saat ini muncul sebagai akibat dari adanya skandal keuangan yang menimpa perusahaan-perusahaan besar seperti Enron dan WorldCom. Lemahnya pelaksanaan corporate governance di perusahaan dianggap sebagai salah satu pemicu utama skandal tersebut.

Good Corporate Governance yang selanjutnya disingkat dengan GCG merupakan alat bagi perusahaan untuk menjaga kerahasiaan perusahaan melalui fungsi kontrol atas operasional perusahaan itu sendiri. Pemahaman terhadap prinsip Corporate Governance telah dijadikan acuan oleh negara-negara di dunia termasuk Indonesia. Di Indonesia, prinsip-prinsip penerapan GCG diatur dalam Pedoman Umum Good Corporate Governance di Indonesia oleh Komite Nasional Kebijakan Governance (KNKG) yang dikeluarkan pada tahun 2006. Pedoman

\footnotetext{
${ }^{78}$ Dosen tetap FH Unwahas Wakil Dekan FH Unwahas, Pengampuh matkul Hukum Dagang Hukum , Perlindungan Konsumen, Pengantar Hukum Indonesia. Dan Hukum Perbankan Syariah.
} 
Umum Good Corporate Governance Indonesia (KNKG: 2006) merupakan acuan bagi perusahaan untuk melaksanakan GCG dalam rangka:

1. Mendorong tercapainya kesinambungan perusahaan melalui pengelolaan yang didasarkan pada asas transparansi, akuntabilitas, responsibilitas, independensi serta kewajaran dan kesetaraan.

2. Mendorong pemberdayaan fungsi dan kemandirian masing-masing organ perusahaan, yaitu Dewan Komisaris, Direksi dan Rapat Umum Pemegang Saham.

3. Mendorong pemegang saham, anggota Dewan Komisaris dan anggota Direksi agar dalam membuat keputusan dan menjalankan tindakannya dilandasi oleh nilai moral yang tinggi dan kepatuhan terhadap peraturan perundang-undangan.

4. Mendorong timbulnya kesadaran dan tanggung jawab sosial perusahaan terhadap masyarakat dan kelestarian lingkungan terutama di sekitar perusahaan.

5. Mengoptimalkan nilai perusahaan bagi pemegang saham dengan tetap memperhatikan pemangku kepentingan lainnya.

6. Meningkatkan daya saing perusahaan secara nasional maupun internasional, sehingga meningkatkan kepercayaan pasar yang dapat mendorong arus investasi dan pertumbuhan ekonomi nasional yang berkesinambungan.

Tata kelola perusahaan yang baik, yang dalam terminologi modern disebut sebagai Good Corporate Governance berkaitan dengan hadits Rasulullah SAW yang diriwayatkan oleh Aisyah r.a yang artinya "Sesungguhnya Allah menyukai apabila seseorang melalukan sesuatu pekerjaan dilakukan dengan baik”. Indonesia sebagai negara yang mayoritas penduduknya beragama Islam, haruslah memahami dan mengetahui prinsip-prinsip Good Corporate Governance dalam konteks keIslaman. Prinsip-prinsip Good Corporate Governance dalam konteks keIslaman bukanlah sesuatu yang baru. Prinsip-prinsip ini telah ada sejak ratusan tahun yang lalu dalam wujud manajemen Islami. Namun dengan berkembangnya prinsip kapitalisme dunia barat, prinsip-prinsip tersebut kemudian ditinggalkan oleh umat Islam.

Entitas syariah di Indonesia saat ini semakin berkembang. Tak hanya di bidang perbankan, asuransi syariah juga turut meramaikan bisnis syariah saat ini. Bisnis syariah yang semakin berkembang saat ini tentu saja memberikan pengaruh terhadap pelaksanaan Good Corporate Governance itu sendiri. Bisnis syariah haruslah berpegang teguh terhadap prinsip-prinsip syariah dengan tidak 
mengecualikan pelaksanaan Good Corporate Governance pada bisnis syariah itu sendiri.

Entitas syariah tentunya memiliki perspektif tersendiri terhadap Good Corporate Governance yang tentunya merupakan cerminan dari perspektif Islam. Berkembangnya bisnis syariah dan Good Corporate Governance di Indonesia turut diikuti oleh dikeluarkannya Konsep Pedoman Good Governance Bisnis Syariah oleh Komite Nasional Kebijakan Governance pada tahun 2011.

Prinsip Good Corporate Governance dalam Islam mengacu pada AlQuran dan Al-Hadits yang menjadikannya unik dan berbeda dengan konsep Good Corporate Governance dalam pandangan dunia barat. Prinsip Good Corporate Governance secara umum adalah transparansi (transparency), akuntabilitas (accountability), responsibiltas (responsibility), independensi (indenpendency), kewajaran dan kesetaraan (fairness). Sedangkan prinsip Good Corporate Governance dalam Islam menurut Muqorobin (2011) meliputi tauhid, taqwa dan ridha, equilibrium (keseimbangan dan keadilan), dan kemaslahatan. Prinsipprinsip Corporate Governance dalam perspektif Islam diwujudkan melalui kerangka syariah dalam pelaksanaan bisnis, keadilan dan kesetaraan demi kemaslahatan serta berorientasi pada Allah SWT sebagai pemilik dan otoritas tunggal di dunia.

\section{B. Rumusan Masalah}

Berdasarkan latar belakang yang telah diuraikan di atas, rumusan masalah ini adalah sebagai berikut.

1. Apa sajakah prinsip- prinsip Good Corporate Governance?

2. Bagaimana Good Corporate Governance ditinjau dari perspektif Islam?

\section{Manfaat Penulisan}

Berangkat dari rumusan masalah di atas, tujuan penelitian ini adalah sebagai berikut.

1. Untuk mengetahui prinsip- prinsip Good Corporate Governance? 
2. Untuk mengetahui Good Corporate Governance ditinjau dari perspektif Islam.

\section{Pembahasan}

\section{a. Pengertian Good Corporate Governance}

Bank Dunia mendefinisikan Good Corporate Governance sebagai kumpulan hukum, peraturan, dan kaidah-kaidah yang wajib dipenuhi, yang dapat mendorong kinerja sumber-sumber perusahaan untuk berfungsi secara efisien guna menghasilkan nilai ekonomi jangka panjang yang berkesinambungan bagi para pemegang saham maupun masyarakat sekitar secara keseluruhan. ${ }^{79}$

Organization for Economic Corporation and Development (OECD) dalam mendefinisikan Good Corporate Governance sebagai sistem yang dipergunakan untuk mengarahkan dan mengendalikan kegiatan perusahaan. Corporate Governance mengatur pembagian tugas hak dan kewajiban mereka yang berkepentingan terhadap kehidupan perusahaan termasuk para pemegang saham, dewan pengurus, para manajer, dan semua anggota stakeholder nonpemegang saham.

Center for European Policy Study (CEPS) memformulasikan Good Corporate Governance sebagai seluruh sistem yang dibentuk mulai dari hak (right), proses, dan pengendalian, baik yang ada di dalam maupun di luar manajemen perusahaan. ${ }^{80}$

Forum for Corporate Governance in Indonesia (FCGI) mendefinisikan Corporate Governance sebagai seperangkat peraturan yang mendefinisikan hubungan antara pemegang saham, manajer, kreditor, pemerintah, karyawan dan stakeholder internal dan eksternal lainnya sehubungan dengan hak dan tanggung jawab, atau sistem

\footnotetext{
${ }^{79}$ Muh .Effendi Arief, The Power of Good Corporate Governance: Teori dan Implementasi. Jakarta: Salemba Empat, 2009.) hlm. 1-2

${ }^{80}$. Sutedi Adrian, Good Corporate Governance. ( Jakarta: Sinar Grafika, 2011 ) hlm. 1
} 
dimana perusahaan diarahkan dan dikendalikan. (Diambil dari Cadbury Komite Inggris). Tujuan dari Corporate Governance adalah untuk menciptakan nilai tambah kepada para pemangku kepentingan.

Berdasarkan SK Menteri BUMN No. 117/M-MBU/2002, Corporate Governance adalah suatu proses dan struktur yang digunakan oleh organ BUMN untuk meningkatkan keberhasilan usaha dan akuntabilitas perusahaan guna mewujudkan nilai pemegang saham dalam jangka panjang dengan tetap memerhatikan pemangku kepentingan (stakeholder) lainnya, berlandaskan peraturan perundangan dan nilai-nilai etika.

Good Corporate Governance, yang selanjutnya disebut GCG, adalah suatu tata kelola Bank yang menerapkan prinsip-prinsip keterbukaan (transparency), akuntabilitas (accountability), pertanggungjawaban (responsibility), profesional (professional), dan kewajaran (fairness) (Peraturan Bank Indonesia No. 11/33/PBI/2009).

Dari berbagai definisi di atas, dapat disimpulkan bahwa Good Corporate Governance merupakan sistem yang mengatur dan mengendalikan perusahaan guna menciptakan nilai tambah bagi para pemangku kepentingan perusahaan dan masyarakat sekitar ${ }^{81}$

\section{b. Prinsip-prinsip Good Corporate Governance}

Prinsip Good Corporate Governance menurut Pedoman Umum Good Corporate Governance Indonesia adalah sebagai berikut.

1. Transparansi (transparency)

2. Akuntabilitas (accountability)

3. Responsibilitas (responsibility)

4. Independensi (independency)

5. Kewajaran dan kesetaraan (fairness)

Prinsip dasar transparansi berhubungan dengan kualitas informasi yang disajikan oleh perusahaan. Kepercayaan investor akan sangat tergantung dengan kualitas informasi yang disampaikan perusahaan. Oleh karena itu perusahaan dituntut untuk menyediakan

${ }^{81}$ Ibid. hlm 2 
informasi yang jelas, akurat, tepat waktu dan dapat dibandingkan dengan indikator-indikator yang sarna. Dengan kata lain prinsip transparansi ini menghendaki adanya keterbukaan dalam melaksanakan proses pengambilan keputusan dan keterbukaan dalam penyajian informasi yang dimiliki perusahaan. ${ }^{82}$

Prinsip akuntabilitas berhubungan dengan adanya sistem yang mengendalikan hubungan antara unit-unit pengawasan yang ada di perusahaan. Akuntabilitas dilaksanakan dengan adanya dewan komisaris dan direksi independen, dan komite audit. Akuntabilitas diperlukan sebagai salah satu solusi mengatasi Agency Problem yang timbul antara pemegang saham dan direksi serta pengendaliannya oleh komisaris. Praktik-praktik yang diharapkan muncul dalam menerapkan akuntabilitas di antaranya pemberdayaan dewan komisaris untuk melakukan monitoring, evaluasi, dan pengendalian terhadap manajemen guna memberikan jaminan perlindungan kepada pemegang saham dan pembatasan kekuasaan yang jelas di jajaran direksi.

Menurut KNKG, responsibility mencerminkan kepatuhan perusahaan terhadap peraturan perundang-undangan serta pelaksanaan tanggung jawab terhadap masyarakat dan lingkungan sehingga dapat terpelihara kesinambungan usaha dalam jangka panjang dan mendapat pengakuan sebagai good corporate citizen.

Responsibilitas diartikan sebagai tanggung jawab perusahaan sebagai anggota masyarakat untuk mematuhi peraturan dan hukum yang berlaku serta pemenuhan terhadap kebutuhan kebutuhan sosial. Responsibilitas menekankan pada adanya sistem yang jelas untuk mengatur mekanisme pertanggungjawaban perusahaan kepada pemegang saham dan pihak-pihak lain yang berkepentingan. Hal tersebut untuk merealisasikan tujuan yang hendak dicapai GCG yaitu mengakomodasi kepentingan pihak-pihak yang berkaitan dengan

\footnotetext{
${ }^{82}$ Arifin, Peran Akuntan dalam Menegakkan Prinsip Good Corporate Governance pada Perusahaan di Indonesia ( Semarang: Fakultas Ekonomi Universitas Diponegoro : 2005)
} 
perusahaan seperti masyarakat, pemerintah, asosiasi bisnis dan pihakpihak lainnya.

Selanjutnya, perusahaan harus dikelola secara independen sehingga masing-masing organ perusahaan tidak saling mendominasi dan tidak dapat diintervensi oleh pihak lain. Fairness menurut KNKG menggambarkan pelaksanaan kegiatan perusahaan yang harus senantiasa memperhatikan kepentingan pemegang saham dan pemangku kepentingan lainnya berdasarkan azas kewajaran dan kesetaraan . Prinsip kewajaran menekankan pada adanya perlakuan dan jaminan hak-hak yang sama kepada pemegang saham minoritas maupun mayoritas, termasuk hak-hak pemegang saham asing serta investor lainnya. Praktik kewajaran juga mencakup adanya sistem hukum dan peraturan serta penegakannya yang jelas dan berlaku bagi semua pihak. Hal ini penting untuk melindungi kepentingan pemegang saham dari praktik kecurangan (fraud) dan praktik-praktik insider trading yang dilakukan oleh agen/manajer. Prinsip kewajaran ini dimaksudkan untuk mengatasi masalah yang timbul dari adanya hubungan kontrak antara pemilik dan manajer karena diantara kedua pihak tersebut memiliki kepentingan yang berbeda (conflict of interest)

\section{c. Good Corporate Governance dalam Perspektif Islam}

Islam mempunyai konsep yang jauh lebih lengkap dan lebih komprehensif serta akhlaqul karimah dan ketaqwaan pada Allah SWT yang menjadi tembok kokoh untuk tidak terperosok pada praktek ilegal dan tidak jujur dalam menerima amanah. Tata kelola perusahaan yang baik, yang dalam terminologi modern disebut sebagai Good Corporate Governance berkaitan dengan hadits Rasulullah SAW yang diriwayatkan oleh Aisyah r.a yang artinya "Sesungguhnya Allah menyukai apabila seseorang melalukan sesuatu pekerjaan dilakukan dengan baik". 
Muqorobin menyatakan bahwa Good Corporate Governance dalam Islam harus mengacu pada prinsip-prinsip berikut ini $:^{83}$

1. Tauhid

Tauhid merupakan fondasi utama seluruh ajran Islam. Tauhid menjadi dasar seluruh konsep dan seluruh aktifitas Umat Islam, baik dibidang ekonomi, politik, sosial maupun budaya..$^{84}$ Dalam Alquran disebutkan bahwa tauhid merupakan filsafat fundamental dari Ekonomi Islam, sebagaimana firman Allah dalam surat Az Zumar ayat 38 :

Dan sungguh jika kamu bertanya kepada mereka: "Siapakah yang menciptakan langit dan bumi?", niscaya mereka menjawab: "Allah". Katakanlah: "Maka Terangkanlah kepadaku tentang apa yang kamu seru selain Allah, jika Allah hendak mendatangkan kemudharatan kepadaKu, Apakah berhala-berhalamu itu dapat menghilangkan kemudharatan itu, atau jika Allah hendak memberi rahmat kepadaKu, Apakah mereka dapat menahan rahmatNya?. Katakanlah: "Cukuplah Allah bagiku". kepada- Nyalah bertawakkal orang-orang yang berserah diri.

Hakikat tauhid juga berarti penyerahan diri yang bulat kepada kehendak Ilahi. Baik menyangkut ibadah maupun Muamalah. Sehingga semua aktivitas ysng dilakukan adalah dalam rangka menciptakan pola kehidupan yang sesuai kehendak Allah.

Apabila seseorang ingin melakukan bisnis, terlebih dahulu ia harus mengetahui dengan baik hukum agama yang mengatur perdagangan agar ia tidak melakukan aktivitas yang haram dan merugikan masyarakat. Dalam bermuamalah yang harus diperhatikan adalah bagaimana seharusnya menciptakan suasana dan kondisi bermuamalah yang tertuntun oleh nilai-nilai ketuhanan. ${ }^{85}$

\footnotetext{
83. Muqorobin Masyudi. , Fikih Tata Kelola Organisasi Laba: Sebuah Pengantar ( Universitas Muhammadiyah : Purwekerto) hlm.4

84. Amiur Nuruddin, Veithzal Rivai, Islamic Business and economic Ethic ( Jakarta : Bumi Aksara, 2012 ) Hlm. 52

85. Mardani., Fiqh Ekonomi Syariah: Fiqh Muamalah. (Jakarta: Kencana. 2012), hlm 6 
2. Taqwa dan ridha

Prinsip atau azas taqwa dan ridha menjadi prinsip utama tegaknya sebuah institusi Islam dalam bentuk apapun azas taqwa kepada Allah dan ridha-Nya. Tata kelola bisnis dalam Islam juga harus ditegakkan di atas fondasi taqwa kepada Allah dan ridha-Nya dalam QS at-Taubah: 109 .

Maka Apakah orang-orang yang mendirikan mesjidnya di atas dasar taqwa kepada Allah dan keridhaan-(Nya) itu yang baik, ataukah orang-orang yang mendirikan bangunannya di tepi jurang yang runtuh, lalu bangunannya itu jatuh bersama-sama dengan Dia ke dalam neraka Jahannam. dan Allah tidak memberikan petunjuk kepada orang- orang yang zalim.

Dalam melakukan suuatu bisnis hendaklah atas dasar suka sama suka atau sukarela. Tidaklah dibenarkan bahwa suatu perbuatan muamalah, misalnya perdagangan, dilakukan dengan pemaksaan ataupun penipuan. Jika hal ini terjadi, dapat membatalkan perbuatan tersebut. Prinsip ridha ini menunjukkan keikhlasan dan iktikad baik dari para pihak

3. Ekuilibrium (keseimbangan dan keadilan)

Tawazun atau mizan (keseimbangan) dan al-‘adalah (keadilan) adalah dua buah konsep tentang ekuilibrium dalam Islam. Tawazun lebih banyak digunakan dalam menjelaskan fenomena fisik, sekalipun memiliki implikasi sosial, yang kemudian sering menjadi wilayah al'adalah atau keadilan sebagai manifestasi Tauhid khusunya dalam konteks sosial kemasyarakatan, termasuk keadilan ekonomi dan bisnis. Allah SWT berfirman dalam QS ar-Rahman ayat 7-9 :

Dan Allah telah meninggikan langit dan Dia meletakkan neraca (keadilan). Supaya kamu jangan melampaui batas tentang neraca itu. Dan Tegakkanlah timbangan itu dengan adil dan janganlah kamu mengurangi neraca itu. 
Dalam konteks keadilan ( sosial ), para pihak yang melakukan perikatan dituntut untuk berlaku benar dalam pengungkapan kehendak dan keadaan, memenuhi perjanjian yang telah mereka buat, dan memenuhi segala kewajibannya.

4. Kemashlahatan

Secara umum, mashlahat diartikan sebagai kebaikan kesejahteraan ) dunia dan akhirat. Para ahli ushul fiqh mendefenisikannya sebagai segala sesuatu yang mengandung manfaat, kebaikan dan menghindarkan diri dari mudharat, kerusakan dan mufsadah. Imam al Ghazali menyimpulkan bahwa mashlahat adalah upaya untuk mewujudkan dan memelihara lima kebutuhan dasar, yakni $:^{86}$
a) pemeliharaan agama (hifdzud-din)
b) pemeliharaan jiwa (hifhzun-nafs)
c) pemeliharaan akal (hifhzul-'aql)
d) pemeliharaan keturunan (hifhzun-nasl),
e) pemeliharaan harta benda (hifhzul-maal)

\section{d. Prinsip Good Corporate Governance OECD dan KNKG dalam Perspektif Islam}

Prinsip Good Corporate Governance dalam Islam juga sesuai dengan yang dirumuskan oleh OECD maupun KNKG. Prinsip-prinsip yang dirumuskan oleh OECD adalah transparansi, akuntabilitas, pertanggungjawaban dan keadilan. Sedangkan prinsip yang dirumuskan oleh KNKG adalah transparansi,akuntabilitas, pertanggungjawaban, independensi dan keadilan. Penjelasan kelima prinsip tersebut dijabarkan sebagai berikut : ${ }^{87}$

1. Transparansi

86. Amiur Nuruddin, Veithzal Rivai, Islamic Business and economic Ethic ( Jakarta : Bumi Aksara, 2012 ) Hlm. 58

${ }^{87}$ Novi Widiyanti Wulandari., Corporate Governance dalam Pandangan Islam: Sebuah Konsep Altertantif dalam Penerapan Good Corporate Governance. (Universitas Jember : 2009) hlm. 104-111. 
Keakuratan juga menjadi prinsip penting dalam pelaksanaan Corporate Governance yang Islami. Informasi yang akurat dapat diperoleh jika sistem yang ada di perusahaan dapat menjamin terciptanya keadilan dan kejujuran semua pihak. Kondisi ini dapat dicapai jika setiap perusahaan menjalankan etika bisnis yang Islami dan didukung dengan sistem akuntansi yang baik dalam pengungkapan yang wajar dan transparan atas semua kegiatan bisnis.

2. Akuntabilitas

Akuntabilitas tidak hanya terbatas pada pelaporan keuangan yang jujur dan wajar, tetapi yang lebih mengedapankan esensi hidup manusia yang yaitu merupakan bentuk pertanggungjawaban manusia kepada Allah sebagai Dzat pemilik seluruh alam semesta. Konsep Islam yang fundametal meyakini bahwa alam dan seluruh isinya sepenuhnya milik Allah dan manusia dipercaya untuk mengelola sebaik-baiknya demi kemaslahatan umat.

\section{Pertanggungjawaban (responsibilitas)}

Pertanggungjawaban keuangan perusahaan juga perlu disampaikan dalam bentuk pengungkapan yang jujur dan wajar atas kondisi keuangan perusahaan. Sehingga pemegang saham dan stakeholder dapat mengambil keputusan yang tepat. Pelaporan keuangan yang benar dan akurat, juga akan mengahasilkan keakuratan dalam pembayaran zakat. Karena dari setiap keuntungan yang diperoleh muslim dalam kegiatan bisnisnya, setidaknya ada 2,5\% yang menjadi hak kaum fakir miskin. Masalah zakat menjadi penting dalam perspektif Islam karena merupakan ciri diimplementasikannya Good Corporate Governance. Pengelolaan perusahaan yang baik tidak hanya bertujuan untuk memakmurkan manajemen dan pemegang saham, tetapi juga masyarakat di sekitar perusahaan tersebut khususnya kaum fakir dan miskin. 


\section{Independensi}

Independensi terkait dengan konsistensi atau sikap istiqomah yaitu tetap berpegang teguh pada kebenaran meskipun harus menghadapi risiko, sesuai pada QS Fushshilat/41: 30 berikut ini.

Sesungguhnya orang-orang yang mengatakan: "Tuhan Kami ialah Allah" kemudian mereka meneguhkan pendirian mereka, Maka Malaikat akan turun kepada mereka dengan mengatakan: "Janganlah kamu takut dan janganlah merasa sedih; dan gembirakanlah mereka dengan jannah yang telah dijanjikan Allah kepadamu".

Independen merupakan karakter manusia yang bijak (ulul al-bab) yang dalam al-Quran disebutkan sebanyak 16 kali, yang diantara karakternya adalah "Mereka yang mampu menyerap informasi (mendengar perkataan) dan mengambil keputusan (mengikuti) yang terbaik (sesuai dengan nuraninya tanpa tekanan pihak manapun).”

5. Keadilan

Prinsip pencatatan yang jujur, akurat dan adil juga telah diatur dalam Al Quran (2: 282). Al-Quran 2: 283 dan Al Quran 21: 47 juga menekankan bahwa pencatatan atas transaksi keuangan harus dilakukan dengan baik dan benar. Orang yang bertanggungjawab atas pencatatan harus dipilih mereka yang jujur dan adil. Sekali lagi, ini menunjukkan Islam menghendaki diselenggarakannya bisnis secara adil dan jujur bagi semua pihak .

keunggulan utama coporate governance dalam perspektif Islam yaitu orientasi utama pertanggungjawaban manajemen perusahaan adalah Allah sebagai pemilik alam beserta isinya. Penerapan etika Islam dalam berbisnis yang menjamin perlakuan jujur, adil terhadap semua pihak juga menjadi acuan utama pengelolaan perusahaan yang baik. Good Corporate Governance dijalankan tidak hanya sebagai bentuk pertanggungjawaban manajemen terhadap pemilik modal, tetapi lebih pada kebutuhan dasar setiap muslim untuk menjalankan syariat Islam secara utuh dan sempurna. Dengan dasar keyakinan kepada Allah maka 
Good Corporate Governance akan memotivasi transaksi bisnis yang jujur, adil dan akuntabel.

\section{E . Kesimpulan}

Berdasarkan SK Menteri BUMN No. 117/M-MBU/2002, Corporate Governance adalah suatu proses dan struktur yang digunakan oleh organ BUMN untuk meningkatkan keberhasilan usaha dan akuntabilitas perusahaan guna mewujudkan nilai pemegang saham dalam jangka panjang dengan tetap memerhatikan pemangku kepentingan (stakeholder) lainnya, berlandaskan peraturan perundangan dan nilai-nilai etika. Good Corporate Governance, yang selanjutnya disebut GCG, adalah suatu tata kelola Bank yang menerapkan prinsipprinsip keterbukaan (transparency), akuntabilitas (accountability), pertanggungjawaban (responsibility), profesional (professional), dan kewajaran (fairness) (Peraturan Bank Indonesia No. 11/33/PBI/2009).

Islam mempunyai konsep yang jauh lebih lengkap dan lebih komprehensif serta akhlaqul karimah dan ketaqwaan pada Allah SWT yang menjadi tembok kokoh untuk tidak terperosok pada praktek ilegal dan tidak jujur dalam menerima amanah. Tata kelola perusahaan yang baik, yang dalam terminologi modern disebut sebagai Good Corporate Governance berkaitan dengan hadits Rasulullah SAW yang diriwayatkan oleh Aisyah r.a yang artinya "Sesungguhnya Allah menyukai apabila seseorang melalukan sesuatu pekerjaan dilakukan dengan baik".

Good Corporate Governance dalam Islam harus mengacu pada prinsipprinsip : tauhid, taqwa dan ridha, kemaslahatan dan ekuilibrium .Good Corporate Governance dijalankan tidak hanya sebagai bentuk pertanggungjawaban manajemen terhadap pemilik modal, tetapi lebih pada kebutuhan dasar setiap muslim untuk menjalankan syariat Islam secara utuh dan sempurna. 


\section{DAFTAR PUSTAKA}

Alquran dan Terjemahnya. Departemen Agama Republik Indonesia

Adrian, Sutedi, Good Corporate Governance. Jakarta: Sinar Grafika, 2011 .

Arifin, Peran Akuntan dalam Menegakkan Prinsip Good Corporate Governance pada Perusahaan di Indonesia Semarang: Fakultas Ekonomi Universitas Diponegoro : 2005 .

Effendi, Muh . Arief, The Power of Good Corporate Governance: Teori dan Implementasi. Jakarta: Salemba Empat, 2009.

Masyudi Muqorobin. Fikih Tata Kelola Organisasi Laba: Sebuah Pengantar Universitas Muhammadiyah : Purwekerto.2011.

Nuruddin Amiur, Veithzal Rivai, Islamic Business and economic Ethic, Jakarta : Bumi Aksara, 2012 .

Mardani., Fiqh Ekonomi Syariah: Fiqh Muamalah.Jakarta: Kencana. 2012.

Widiyanti , Novi Wulandari., Corporate Governance dalam Pandangan Islam: Sebuah Konsep Altertantif dalam Penerapan Good Corporate Governance.Universitas Jember : 2009. 